\title{
Geochemistry and Sr-Nd isotopic compositions of Beijie pluton from Northwestern Jiaodong Peninsula, eastern China
}

\author{
Y.X.SONG, D.P.LI*, K.GENG, P.F.WEI, L.SHU AND \\ H.Q.WANG
}

Shandong Institute of Geological Sciences, Jinan 250013,China(songying.xin2008@163.com;*correspon dence:dpengli@126.com)

The Northwestern Jiaodong Peninsula is the most impoatant gold mineralization area in China. The majority of gold resources $(>95 \%)$ in Jiaodong are hosted in the Late Jurassic Linglong-type and Early Cretaceous Guojialing-type granitoids. However, there is still controversy over the petrogenesis. The Guojialing granitoids which intruding into the Linglong granitoids, including six plutonic bodies from east to west: Guojialing, Congjia, Beijie, Shangzhuang, Xincheng and Sanshandao.

The Beijie granodiorites are characterized by high concentrations of $\mathrm{K}_{2} \mathrm{O}+\mathrm{Na}_{2} \mathrm{O}$, LILEs (e.g., $\mathrm{Ba}$ and $\mathrm{Sr}$ ), LREEs, $\mathrm{Sr} / \mathrm{Y}$ and $(\mathrm{La} / \mathrm{Yb})_{\mathrm{N}}$ ratios, with low $\mathrm{Al}_{2} \mathrm{O}_{3}, \mathrm{MgO}$, HFSE s(e.g., $\mathrm{Y}$ and $\mathrm{Yb}$ ) and HREEs. All these features suggest that the rocks belong to the high $\mathrm{Ba}-\mathrm{Sr}$ granites which are considered to be crust-mantle origin. Their $\mathrm{Sr}-\mathrm{Nd}$ isotopic compositions are similar to the Linglong type granite and mafic dykes from Jiaodong, indicating the Beijie pluton might be generated by partial melting of acidic magmas from lower crust mixed with basic magma derived from mantle.

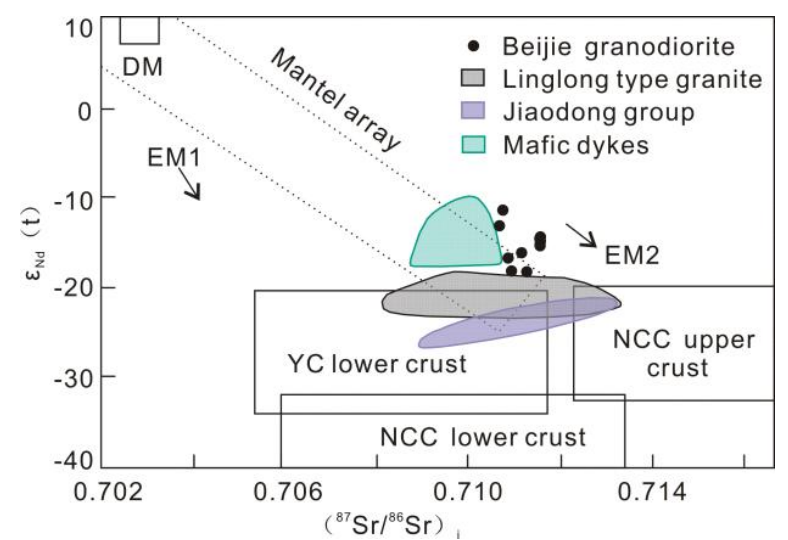

Fig.1: $\varepsilon_{\mathrm{Nd}}(\mathrm{t})$ vs. $I_{\mathrm{Sr}}$ diagram for Beijie granodiorite from the Jiaodong Peninsula [1]

[1] Defant and Drummond (1990) Nature, 34:662-665. 